\title{
Vulnerability and Climate Change Perceptions: A Case Study in Brazilian Biomes
}

\author{
Teresa da Silva-Rosa ${ }^{1}$, Michelle Bonatti ${ }^{2}$, Andrea Vanini ${ }^{3} \&$ Catia Zuffo ${ }^{4}$ \\ ${ }^{1}$ Vila Velha University, Center of Socioenvironmental and Urban Studies -- NEUS/UVV, Brazil \\ ${ }^{2}$ University Buenos Aires -UBA, Argentina \\ ${ }^{3}$ Technical Office for Management and Environmental Education at the Fiocruz Atlantic Forest Campus, Brazil \\ ${ }^{4}$ Federal University at Rondônia - UNIR, Brazil \\ Correspondence: Teresa da Silva Rosa, Núcleo de Estudo Urbanos e Socioambientais/NEUS, Programa de Pós \\ Graduação em Sociologia Política/PPGSP - UVV-ES, Rua Comissário José Dantas de Melo, 21, Boavista - Vila \\ Velha, Espírito Santo, Brazil. E-mail: tsrosaprof@yahoo.com.br
}

\author{
Received: February 1, 2013 Accepted: March 23, 2013 Online Published: January 1, 2014 \\ doi:10.5539/ep.v3n1p82 URL: http://dx.doi.org/10.5539/ep.v3n1p82
}

\begin{abstract}
Based on the assumption that vulnerability is socially constructed, and may thus change according to transformations in human action, it appears necessary to consider the issue at the core of studies on the social aspects of Climate Change (CC), risk level and disaster prevention. The social nature of vulnerability is determined by elements such as poverty, inequality, exclusion and access to sanitation, water, food and education among other factors.

In 2010, a study was undertaken in the ambit of the project "Climate Change, Social Inequalities and Vulnerable Populations" about the perception of and an assessment of vulnerability. Information was gathered through interviews using structured questionnaires administered in communities in three Brazilian biomes: the Atlantic Forest, the Amazon and the Semi-Arid and Cerrado region. This paper discusses the result of three case studies: one in Rondonia in the Amazon, and two in the Atlantic Forest biome, one in Rio de Janeiro and another in Santa Catarina.

Two points in common among the communities should be highlighted. (1) None of the communities have plans or actions to adapt to natural climate variability, much less to CC. This makes the communities more vulnerable and unprepared to act with protective or reactive preventive measures. (2) Thus, it is important to develop a plan with actions that address the situation of "organized irresponsibility", understood as a network of mechanisms that treat environmental problems as normal, or regard them as being of governmental responsibility alone.
\end{abstract}

Keywords: climate change, social organization, vulnerability

\section{Introduction}

The paper is based on research that was the result of a collective endeavor by social actors from distinct backgrounds who are involved in Brazilian environmental governance, including academia, organized civil society, and government. The aim is to shed light on the understanding of climate change (CC) found in a variety of Brazilian communities. The study emerged from activities of the national network known as the Committee of Entities in the Fight on Hunger and for Life (National COEP) (Note 1) undertaken among economically under privileged communities throughout Brazil, with the common purpose of developing actions against poverty.

As a member of the Brazilian Forum for Climate Change (Fórum Brasileiro de Mudanças Climáticas/FBMC), COEP raised the issue of social inequality at this forum, propitiating the creation of the working group "Climate Change, Poverty and Inequality", as of April 2009. One of the major activities (Note 2) of this working group is the study "Climate Change, Social Inequalities and Vulnerable Populations in Brazil: Building on Skills" along with two subprojects, one of which addresses corporations, and the other vulnerable populations. This paper is concerned with the latter, and was coordinated by the Reference Centre for Food and Nutrition Security (Centro de Referência em Segurança Alimentar e Nutricional/CERESAN) at the Federal Rural University at Rio de Janeiro (UFRRJ), and the Centre for Urban and Socio-environmental Studies (Núcleo de Estudos Urbanos e 
Socioambientais/NEUS) at the University of Vila Velha (UVV-ES). A number of researchers with different academic backgrounds from two Brazilian universities (Note 3), and one research institution (Note 4), located in different biomes (Note 5) and close to communities presenting specific socio-economic scenarios were involved in the study. The research was made possible by funding from the Ministry of Science, Technology and Innovation (MCTI) through the National Council for Scientific and Technological Development (CNPq), and by research scholarships for scientific initiation from the National Foundation for the Development of Private Higher Education (FUNADESP).

The research was organized around three interconnected themes (Note 6), and this paper focuses on case studies about the vulnerability and capacity for adaptation of selected populations from distinct biomes. One is in the Amazon, where the focus is on a riverine community located within a project for settling previously landless families, which is part of the federal government agrarian reform program in Rondônia state. The two other communities are located in the peripheries of the metropolitan regions of Rio de Janeiro and Florianópolis, in the Atlantic Forest biome.

In Brazil, intense weather events can have impacts on the populations and economies of big cities, small towns and rural areas that create states of emergency or calamity. Losses in agricultural yield, infra-structure damage and the number of victims from such disasters in recent decades prompt us to pursue a broader understanding of these phenomena, and more effective actions by the communities and government to mitigate the negative effects by more thorough preparation to protect against these events.

The approach adopted here presupposes that the climate issue, similarly to other environmental matters, creates an opportunity to review the current basis of economic development, particularly the use of natural resources. The form of this use is made more apparent by the approach that exposes the many degrees of vulnerability of the populations, in particular those that are already in a situation of risk as a result of their social and economic exclusion, especially in countries with late development such as Brazil. In other words, we begin from the premise that the vulnerabilities suffered by the populations are historically constructed by a development model that creates socio-economic inequalities (Valencio et al., 2009; Mattos \& Da-Silva-Rosa, 2011; Da-Silva-Rosa \& Mattos, 2012), placing the excluded populations in situations of risk or vulnerability because they occupy regions such as floodable areas, hillsides, and river banks that for this reason are designated areas for permanent environmental preservation by Brazilian law.

In this context, it is important to consider the disproportional imposition of environmental risk on populations with less financial, political and informational resources. This situation has become known as environmental injustice (Acselrad, 2009). According to this concept, poor populations are driven to live in areas more subject to flooding, landslides and other environmental problems.

These risky situations exist before the occurrence of extreme weather events, which aggravate the existing vulnerabilities. This makes it inappropriate to speak of "natural" disasters, because in fact they are usually socio-environmental problems that are made evident by natural events. It is worth noting that these events do not only affect economically disadvantaged populations, as seen in the disaster that occurred in the mountainous region of Rio de Janeiro state, in January 2011 (Note 7), although the populations in historic situations of exclusion constitute the majority of those who suffer in the disasters. This prompts us to suggest that climate-related events are not the prime causes of so-called socio-environmental disasters, but rather reveal concrete situations of vulnerability.

In the aftermath of these events, it can be observed that government commonly declines to enforce environmental laws that prohibit the occupation of areas designated for permanent preservation; and also fails to implement public policies that would satisfy the needs of low income populations for education, healthcare, housing and sanitation. Moreover, it is clear that the affected communities are "unprepared" to react promptly and in advance against imminent risks, revealing their inability to adapt to increasingly recurring situations.

This paper reflects on some key concepts related to the social dimension of climate change and vulnerability; it then presents and discusses the results of three case studies undertaken in different socio-environmental situations in Brazil.

This paper understands vulnerability to be the incapacity to deal with danger, and it can refer both to natural and social systems (Fussel \& Klein, 2006; O’Riordan cited in Braga et al., 2006). With Regards to The Social System, Vulnerability Refers to the Fragility or Precariousness of the Living conditions of a group, which hinders a population's capacity to react to or confront the impacts of an event, whether because of its unpredictability or its intensity. Vulnerability, as highlighted by O'Riordan (cited in Braga et al., 2006) is "...a consequence of a combination of economic, social, environmental and political processes" (p. 2), which 
exemplifies the level of complexity that must be acknowledged when tackling such issues. Vulnerability may also be understood as being an "....intrinsic condition to...the receptor system, which in interaction with the magnitude of the event..., defines adverse effects..." (Valencio, 2011, p. 9).

The categorization "socially and environmentally vulnerable populations" indicates the fact that these populations face a dual exposure (O'Brien \& Leichenko, 2000). After all, not only are they living in a condition of social exclusion and deprived of basic needs (due to unjust development models), but they are also placed in a situation of environmental vulnerability, exactly because of the socio-economic exclusion and injustice to which they are submitted, considering that they are pushed to occupying areas of risk or of environmental degradation (Alves, 2006). There is, therefore, a tendency towards a spatial overlapping of socio-economic and environmental problems (Alves, id.). In addition to biophysical factors (such as declivity, vegetation and soil impermeability), social factors contribute to vulnerability, as pointed out by Cardona (2003). Thus, a situation of deprivation, which generally speaking characterizes poorer populations, fragile infra-structure, and precarious public services are some contributing factors. Brazilian studies that analyze vulnerability in urban areas describe these variables as socio-economic and socio-demographic factors (Mello et al., 2010; Alves et al., 2010; Gamba, 2010).

Furthermore, other research shows a relationship between vulnerability and risk. Jacobi (1995) suggests a relationship between precarious or nonexistent public services (such as sewage and garbage collection) and greater exposure to environmental risks. The exposure to risk of disease (such as Leptospira epidemics, typically associated to floods) is directly related to extreme weather conditions, as suggested by Confalonieri (2003). This reveals the interdependency between risk from disaster and the vulnerable structural characteristics of a community. Given that the notion of double exposure is inherent to the concept of socio-environmental vulnerability, a situation of double exposure was one of the criteria for the selection of the social groups that took part in this study.

For the reasons presented, we suggest that a state of vulnerability makes a population highly prone to greater suffering from the unprecedented weather events that have recently occurred in Brazil (including intense rain, long-term droughts and tornados). The social concern for the damage and losses (the disasters) caused by natural or human phenomena are included in this affirmation, yet it is not clear that vulnerability is the cause of the disasters in contemporary times. After all, vulnerability, risk and disaster are closely related. According to Cardona (2003), the risk of disaster is composed of two factors: threat and vulnerability. For the author, threat corresponds to an external factor that may be forecasted, but is usually difficult to control, such as heavy rain, hurricanes or earthquakes. Vulnerability is an internal factor that represents the degree of susceptibility of a system or subject, to a threat. Vulnerability thus constitutes the condition of a threatened subject in his or her social system, and for that reason, it can be understood as a social state. Cardona also suggests that a decrease in the levels of threat and vulnerability may lead to a decrease of risk as a whole. Nevertheless, considering that vulnerability is a socially constructed state, it is therefore, susceptible to change by human agency.

This analysis suggests that addressing historically constructed vulnerability, and adopting measures to foster the capacity to face risks from extreme events should be the underlying concerns in the mitigation of disasters. We therefore agree with Marchezini (2009) who affirms that “...the nature of disasters must be sought in social organization, understanding them as a process associated with social vulnerability, the causes of which must be explained as structural problems, and duly contextualized." (p. 50). This implies the need to reconsider the idea that a disaster is an eminently natural event (and thus referred to as a natural disaster), and contextualize it historically as a socially constructed process resulting from exclusionary conditions and social inequalities caused by a given development model (Valencio et al., 2009). Thus, within the context of CC, the term natural disaster has been replaced by the expression social or socio-environmental disaster.

Populations living in the Third World are considered the most vulnerable, and especially children, women and the elderly (Cardona, id.; BRASIL/PNMC, 2009), even if vulnerability is not restricted to these populations (O'Brien \& Leichenko, 2000) as evident in the disaster of January 2011 in the mountainous region of Rio de Janeiro (Brazil). On that note, three aspects related to vulnerability are highlighted by the work of Moser (1998) and Cardona (2003): (i) the exposure of populations to climate events such as droughts, floods, landslides or cyclones; (ii) the susceptibility of these groups to risky events; and (iii) the resilience or adaptive capacity of vulnerable populations to withstand those events and disasters.

Nevertheless, the discussion of vulnerability and conditions of deprivation, or poverty, reveals that the adaptation measures must consequently prioritize improving conditions by deploying strategies to meet basic needs to minimize situations of risk, and consequently disasters. It is worth clarifying that adaptation is a process and 
concept that is central to this study. For this reason it is necessary to discuss this term to better understand the reasons that led researchers to the field with a questionnaire based on this concept.

These adaptation measures follow similar guidelines as those in the human rights field as suggested by Sachs $(2003 ; 2008)$. In the context of CC, the notion of adaptation emerged with greater strength after CoP13, in Bali (2007), as a consequence of the Fourth Evaluation Report by the IPCC. The late arrival of adaptation as a concern is noteworthy, when compared to mitigation, but it is nevertheless a growing concern, as noted by Klein et al. (2003), while they are both the sustaining pillars of the social dimension of CC.

The underlying purpose of adaptation measures is, in other words, to decrease the probability of the occurrence of disasters, by mitigating vulnerable situations, risk exposure, or insecurity caused by deprivation. This involves increasing the adaptation capacity of vulnerable populations through a change of values and behavior by enhancing awareness among these populations about more sustainable and just ways of life.

The Fourth Report by the IPCC describes adaptation as the capacity to adjust to change, or to react to impacts from climate and non-climate events and to mitigate harm, while taking advantage of opportunities spawned by the respective adversities. The report attempts to link the capacity for adaptation to social and economic development, which, in our view, reinforces the need to establish more sustainable and just ways of life fostered by changes in values and behavior.

On this note, adaptation should be understood not as a simple matter of adjustment as inferred in the definition by the IPCC, but as a skills-building process needed to prepare populations to face impacts resulting from weather variations. This approach differs from one that focuses on adjusting to a given event, since it occurs prior to the occurrence of the extreme event. The process requires evaluating the probable scenarios that could arise from climate or weather conditions and assess the vulnerabilities of communities, such as those that occupy hillsides and unstable land, or areas susceptible to floods.

In this line of reasoning, the capacity to adapt is related to resilience, which is the capacity some systems have to react or resist impacts, and requires greater flexibility from the elements of the impacted system. According to Homer-Dixon (2009), the resilience of both social and complex systems is a property that, with proper strengthening, can avoid disasters, but which requires a cultural change based on the strengthening of systemic connections, while encompassing all the components of a social group.

This process therefore requires a preliminary diagnosis of the community that will participate in the action, to identify the respective vulnerabilities. Afterwards, and with the due participation of the community members, those involved can search for ways to strengthen characteristics intrinsic to existing adaptation strategies and overcome the vulnerabilities identified. In both cases, the aim should be for the community to achieve ecological sustainability, social justice, and a capacity for resilience. This brings us to two points that must be highlighted. Firstly, resilience cannot be strengthened without prior identification of vulnerabilities (Giddens, 2009). Secondly, one must acknowledge the local aspect of the adaptation measures to be undertaken. The latter point illuminates the close relationship of the cultural, social, economic and ecological characteristics of the communities in question (IPCC, 2007).

The local aspect both characterizes adaptation and differentiates it from mitigation, as evidenced by the National Plan for Climate Change (Plano Nacional de Mudanças Climáticas - BRASIL, 2008) which states that "Adaptation actions - contrary to those of mitigation, whose results are reflected globally - are normally perceived in the place where they are carried out, granting adaptation a high degree of specificity" (p. 102). Although the scales of adaptation actions may be distinct (national, municipal, or even pertaining to a particular watershed), the local aspect actually influences the elaboration and choice of measures, reinforcing the already mentioned aspect of the connection between development, adaptation and vulnerability. After all, adaptation measures attempt to minimize the vulnerability of communities while, according to the National Plan, they “...promote better living conditions including housing, food, healthcare, education, employment...[which means that the promotion of sustainable development]...is the most efficient way of fostering resilience in situations of climate change" (BRASIL, 2008, 102). The opportunity to take adaptation measures to improve many areas is thus proposed, favoring, for example, infrastructure less likely to emit greenhouse gases (GHG), without forgetting the need for community empowerment to better prepare it to react promptly when under stress, and when facing destabilization of social and environmental systems.

On that note, adaptation has been seen by the literature as a skill-building process for populations to better adapt to impacts, associated to Homer-Dixon's notion of resilience as the strengthening of systemic connectivity. This is above all a process of political construction of citizenship, which contributes to the empowerment of people while, in the case under analysis, fostering the mobilization of a community to react promptly against adversities. 
This notion relates to what Lemos (2007) considers the double adaptation process: the identification of vulnerabilities, and the construction of preparedness plans, focusing on risk management. With regards to this management, the author identifies three main factors in the construction of resilience systems: adoption of good governance principles by those who elaborate management plans; the essential role of the political networks that orient that governance; and the importance of democratizing knowledge for decision making. These three points are closely related to the constructive intervention perspective of Sen (PNUD/RDH, 2008).

It seems apparent that this skill building process differs from public policies normally adopted in Brazil, which usually focus on emergency actions, and are not deemed efficient for a conscious mobilization of the population since they lack the empowerment aspect characterized by independent, participatory and responsible actions. The role of public policies in the context of $\mathrm{CC}$ should be geared towards stimulating pro-activity, rather than focusing on reaction (Giddens, 2009). This brings us to two distinct approaches for the skills building process related to adaptation: induced adaptation, and spontaneous adaptation. The former is that induced or promoted through public policies by means of a skills building process related to adaptation. It is the perspective known as the institutional approach (UNFCCC, 2006). The latter is the autonomous approach (ibid), in other words, it is the one that is promoted by the community often through existing strategies, and for that reason it is historically consolidated.

\section{Area Descriptions}

In this section three case studies will be presented, and their specificities highlighted. First, each case study is contextualized, and an assessment of the vulnerabilities is presented. The perceptions of the resident families (the key-actors) are introduced and finally a chronology of the local actions based on the identified outcomes. It must be highlighted that in the presentations below, we sought to maintain the particular approaches of the authors responsible for each case study.

\subsection{FIOCRUZ CAMPUS - Atlantic Forest (Rio de Janeiro State)}

The region of the communities studied is an Atlantic Forest fragment in Rio de Janeiro state that had been occupied by large sugar-cane plantations that were transformed to coffee plantations, until the land was transferred to the government. A hospital complex was constructed in these regions to treat mental health problems, tuberculosis and leprosy. Therefore, part of the population in these communities are descendants of former slaves, farm workers, and employees who worked at the hospitals and who received permission to live there, as well as patients who did not have families and were encouraged to marry and form families.

Four urban communities located inside the FIOCRUZ campus in a buffer zone of the Pedra Branca State Park, were studied: Sampaio Correa, Caminho da Cachoeira, Viana do Castelo and Faixa Azul, with a total of 96 families. The Fiocruz campus of the Atlantic Forest (CFMA) is located on land that encompassed a group of psychiatric hospitals known as the Juliano Moreira colony, in Jacarepaguá, and encompasses an area of $5,097,150.24 \mathrm{~m}^{2}$. Fiocruz is a government-affiliated health research organization.

The mostly low-income population that resides in these irregular urban settlements feel generally insecure about their permanence, given that it is an extremely environmentally fragile place, particularly due to the floods that are commonly hazardous to health. The main vulnerability factors among the communities under analysis are poor infrastructure, in terms of garbage collection, water supply, and basic sanitation. These shortcomings contribute to the propagation of disease in the region, and can be intensified by extreme weather events. This territory is therefore characterized by situations of socio-environmental vulnerabilities.

Thus, the objective of this case study was to contribute towards the construction of a shared process of knowledge production about the territory in question, to empower the populations to better face the challenges brought about by extreme weather events in the four communities located in the campus. The communities were selected based on socio-environmental vulnerability factors (Tables 2 and 3 attached), and environmental challenges already faced, focusing on those that may be related to the effects on the environment and health, and those caused by climate change.

A total of 36 families were interviewed (procedure 4), five interviews with local actors (procedure 3) and 12 participants of the focus group (procedure 2).

\subsection{AMAZON - the Gleba Aliança Case Study (Rondonia State)}

There have been many experiments in the Amazon region with policies related to population and economic development, which, nevertheless, have failed to integrate communities to the local biodiversity. With the growth of global apprehension about climate change, concern over deforestation in the Amazon has also 
increased, since according to Marengo (2006), the impacts resulting from deforestation can lead to a rise in temperature, rainfall evaporation and surface drainage.

This characterization results from the case study undertaken at Gleba Aliança, a rural region $30 \mathrm{~km}$ northeast of the center of Porto Velho, capital of Rondônia state (ZUFFO et al., 2010).

Regarding the methodology (procedure 3), the local actors interviewed included five women, and one man: who was a fishing community leader, and president of the Association of Small Farmers of Gleba Aliança AGRILANÇA; and four government employees, with distinct backgrounds (a university lecturer and environmentalist, a journalist, an economist, and a researcher with a background in social communication). To identify the perceptions and vulnerabilities about climate change, a sample questionnaire was given to 47 riverine dwellers (Table 1): traditional populations, small farmers and cattle raisers, all residents in the five communities of Gleba Aliança.

According to the Agrarian Reform Information System (SIPRA) produced by the National Institute of Colonization and Agrarian Reform (INCRA), Gleba Aliança, became federal property in 1990 (MAGALHÃES, 2005). It is divided into three micro-regions with characteristics specific to its occupation process, namely: one portion is a Settlement Project (Projeto de Assentamento - PA) Aliança, and two others are spontaneous occupations. The latter are areas of land tenure regularization, one of which is located on solid ground, while the other is on flooded plains on the shores of Cujubim Grande lake and the Candeias, Jamari and Madeira rivers.

During the field activities in June and July 2010, it was observed that the most present segment, among the traditional population of the Amazon biome under study are the riverine communities, concentrated especially in the locality referred to as "Agrovila" (which is located in the Gleba Aliança).

\subsection{TAPERA DA BASE - Atlantic Forest (Santa Catarina State)}

Climate adversities have significantly affected Santa Catarina state throughout its history, mostly as a result of some specific features in the region, namely: high rainfalls and heavy storms contrasted by droughts that can last many months. According to the "Natural Disasters Caused by Climate Adversities in the state of Santa Catarina Assessment (1980-2000)", this is one of the states where there has been an increase in the occurrence of storms that lead to declarations of a state of emergency or public calamity (Herrmann et al., 2001). One of the communities where these events take place is Tapera da Base.

Located $27 \mathrm{~km}$ south of the center of Florianópolis, Santa Catarina state, in 2010, Tapera da Base had a population of around 12 thousand people. Part of the municipality of Florianópolis, the community is situated between an ocean bay and a mangrove, and there is an Air Force Base between the community and the center of the city. The village has had an ongoing process of occupation, encompassing modest to very precarious housing.

Most of the houses are built on terrain with high water levels that are strongly affected by the tides. About half are on lots less than two meters above sea level, which makes them vulnerable to flooding. Near the mangrove, clandestine subdivisions and other lots are occupied on landfill composed of a wide range of materials that are usually inadequate to sustain tidal dynamics and human health. Thus, a combination of factors such as high tides, lack of storm sewerage, the soil quality and topography of the region and impermeable structures contribute towards the occurrence of high impact floods, by hindering the drainage of water from intense rainfalls. For that reason, rainfalls are seen as a daily risk by the population. Constant flooding in the mangrove region affects almost half of the inhabitants in the community of Tapera da Base.

To assess the living conditions of some of these populations, the State Secretariat for Urban Development and the Environment of Santa Catarina (SDM/SC) applied the Local Human Development Index (IDHL) to 88 neighborhoods in Florianópolis (Cesa, 2008). According to the CESA (2008) index, although living conditions improved between 1991 and 2000, they are not uniform throughout the city. Tapera da Base came in 84th place among the 88 neighborhoods analyzed.

Independent of possible problems related to climate change, the population of Tapera da Base is vulnerable to common and daily weather alterations. This vulnerability is determined by the difficulties of the location, and by the lack of public policies, as well as by the nature of the social reproduction of particular groups in the community. This is particularly the case of the collectors of berbigão (the common cockle) in the region, and of the residents of more flood-prone streets, as indicated by the interviews with the families.

Considering the extension and quantity of Tapera's population, it was decided to focus the interviews on the regions with the most vulnerable household's. Therefore, the interviews were conducted with 16 families from two segments of the community who were indicated by the community council as the most vulnerable to climate 
dynamics, more specifically 8 families of cockle collectors and 8 families living on Rua da Juca (Table 1). The vulnerability of these segments is related to the increasing difficulty for the families to survive through shellfish collection and by the frequent flooding of their homes, respectively.

Table 1. Total monthly family income of those interviewed percent by state and total

\begin{tabular}{lccc}
\hline Range & $\begin{array}{c}\text { Rio de } \\
\text { Janeiro }\end{array}$ & $\begin{array}{c}\text { Rondonia } \\
\text { Catarina }\end{array}$ \\
\hline Up to US\$ 691.56 (R\$ 1.500) & $75 \%$ & $87 \%$ & $100 \%$ \\
$\begin{array}{l}\text { US\$ 691.56 (R \$1.500)- } \\
\text { US\$ 1,383.12 (R\$ 3.000) }\end{array}$ & $22 \%$ & $9 \%$ & $0 \%$ \\
$\begin{array}{l}\text { More than US\$ 1,383.12 } \\
\text { (R\$ 3.000) }\end{array}$ & $3 \%$ & $4 \%$ & $0 \%$ \\
\hline
\end{tabular}

\section{Methods}

The choice of communities for the case studies was based, on one hand on the criteria of socio-spatial, environmental and cultural diversity in the country. The case study sites are located in areas with high frequencies of extreme climate events, which can make their populations more vulnerable. The selection of case studies and interviewers was designed to promote dialog with people who are directly affected by extreme climate events, particularly flooding and drought. Populations located in areas where activities had previously been undertaken by researchers and institutions belonging to the National Mobilization Network COEP, were given prioirty. Furthermore, there were two other preponderant considerations: the various Brazilian biomes, and the rural and urban populations in the large metropolitan centers in the country.

The research focused on a study of the communities, their territory and culture, as suggested by the literature, exploring the populations' perceptions and recognition of climate phenomena. The focus on the local dimension is also justified by the interest in investigating the capacity of each community to engage with the institutions present in its territory, and of its members to organize themselves as citizens at the local level. Thus, the research undertaken in 2010 entailed four procedures common to all the case studies:

(1) Identification of social actors present in the communities (local governmental institutions, non-governmental organizations among others) and their programs;

(2) Configuration of focal groups for discussion of pre-established themes;

(3) Interviews with the most relevant local actors; and

(4) Presentation of standard questionnaires to the families that made up the sample.

Table 2. Number of families interviewed in rural and urban areas by state

\begin{tabular}{lcccc}
\hline Rural or Urban & $\begin{array}{c}\text { Rio de } \\
\text { Janeiro }\end{array}$ & Rondonia & $\begin{array}{c}\text { Santa } \\
\text { Catarina }\end{array}$ & Total \\
\hline Rural & 0 & 47 & 0 & $\mathbf{4 7}$ \\
Urban & 36 & 0 & 16 & $\mathbf{5 2}$ \\
\hline Total & 36 & 47 & 16 & $\mathbf{9 9}$ \\
\hline
\end{tabular}

In addition to the specificity of each one of these procedures, the number of informants in the study also sought to respect the social characteristics of the areas studied. Two criteria were adopted to define the number of people interviewed, or who would be given the questionnaire that is part of the fourth methodological procedure above. The first was that more than $15 \%$ of the sample in each community should be from vulnerable households. Thus, the number of respondents was considered sufficient when it was possible to identify a pattern or common terms found in the material, allowing the establishment of generalizations. The second is that the respondents were present when the questionnaires were issued. Thus, the composition of the sample is not the same for the three case studies, except the fact that they were people living in a vulnerable area or in a historically vulnerable situation. 
Five key questions orientated the case studies based on the work of Smit et al. (cited in Fussel \& Klein, 2004), and on the document by UNDP/GEF (Note 8):

(1) Adapt to what? - Climate variations (projected patterns of temperature and rainfall), threats and vulnerabilities, risks and answers suggested by the resulting information.

(2) Who will be affected? - Socioeconomic conditions of vulnerable communities and groups in specific risk situations.

(3) What will be affected? - Threats and impacts that will probably have to be faced by the vulnerable group, and possible causes that justify those vulnerabilities. Some areas of impact identified in the literature as vulnerable, or seen as being in situations of risk (biodiversity, water, agriculture/food, health, housing), were selected for the research.

(4) How to adapt? - Measures to reduce vulnerabilities, or risk management already in place in the community, other adaptation measures that could possibly be adopted by the community based on examples; opportunities and difficulties to implement the reduction measures, or risk management identified; identification of actors/partners who may become involved.

(5) How adequate is the adaptation proposal? - It is necessary to know the contextual situation of the area where probable impacts and adaptation strategies will be implemented.

\section{Results and Discussion}

Considering the different social contexts found in each case study, the results will be presented and discussed according to geographic region. The paper will only discuss the data related to the key questions in the study.

In the case of the Fiocruz Campus, the interviewees that belonged to the family groups reported that temperature variations coincided with a higher incidence of mosquitoes that carry disease. They also noted that the environment is degrading due to construction in coastal areas, deforestation and pollution, including the establishment of a quarry nearby.

The social actors interviewed associated climate variations with human activities, even if they did not see themselves as being responsible either for improving or changing the scenario.

It can be observed that the interviewees in the family group have no adaptation plans for the climate events taking place in these communities. Some of the families interviewed reside in areas where Brazilian environmental law prohibits construction, known as Areas of Permanent Preservation (APPS), because they are close to water, a fact that increases their vulnerability to increases in the volume of rainfall. Nevertheless, there was no mention of how to foster adaptation to the recurring floods in this region, which were deemed common by the residents. Heavy rainfall also provokes landslides on hilly sites, which can threaten housing.

Since the communities in the study are located in the buffer zone of the Pedra Branca State Park, they are also susceptible to high levels of humidity, and are close to disease vectors and reservoirs. The high humidity affects houses with poor ventilation and aggravates respiratory problems and allergies resulting from fungi and parasitic mites. In the broader scope of this study, the populations were also monitored to gauge the control of these diseases over the years, so that they do not get worse, in the case of possible extreme climate events.

Based on the results above, some propositions for an action plan can be indicated. As a strategy for risk mitigation in future action plans of the communities under study, it is worth mentioning the enactment of a plan to regulate land tenure coordinated by FIOCRUZ, including the reallocation of families in areas of risk to nearby areas, in accord with current legislation. New houses will be built on lots of around $400 \mathrm{~m}^{2}$, while residents who remain in their residences will participate in a residential improvement program. Moreover, a contingency plan is being developed, with the participation of FIOCRUZ, the state department of Civil Defense, and the community. Lastly, in addition to the above initiatives, the populations were included in the federal works project known as PAC - to receive sanitation and street paving, and improved access to public transportation, which was precarious at the time of this research.

In addition to these projects, it is also important to focus on the reduction of deforestation and forest fires in the area, the disposal of waste in appropriate locations, a more efficient garbage collection system and an ecological restoration project. These kinds of mitigating strategies offer direct and indirect benefits, such as: reducing the risk of landslides, maintenance of the local micro climate, a decrease in the proliferation of disease-transmitting vectors, reduction of waterway sedimentation and subsequent reduction of flood risks.

Evaluating the issues of "Adapt to what" or "What will be affected" the aspects most cited were: deforestation, floods and invasion of land for real estate speculation. About "What would be a suitable local action plan," the 
relocation of houses to areas not subject to flooding and landslides should be considered as well as the elimination of the use of fire to clear pasture and burn garbage. More recently, the community became part of the rain alert plan promoted by the Rio de Janeiro state civil defense agency, which will alert residents by cell phone about the arrival of heavy rain.

In the Amazon case, the significance of the principal changes in local conditions observed by those interviewed in the Gleba Aliança in Rondônia cannot be overemphasized. From the most to the least important they include: changes in volume and season of rainfall, changes in temperature, interruption of water supply, and changes in agriculture, small-scale cattle rearing, and extractivism (collection of natural products such as Brazil nuts, açaí fruit and vegetable oils - copaiba and andiroba). Since there are different population groups (riverine populations, small farmers, and cattle raisers) in Gleba Aliança, the study understood that the characteristics and degree of climate vulnerability are different for each group. The information gathered in the interviews point to a variety of factors regarding the areas suffering impacts selected by the study and climate-change related events.

It was perceived that the time of residence in the location is reflected in the type of construction, its suitability and conservation as well as in family size. In terms of health issues and basic sanitation, the situation is a bit precarious and concerning vectors of tropical diseases, a high rate of malaria was found. In relation to water, in the months of June and August, due to the drop in rainfall, a good portion of the igarapés (forest waterways) suffer considerable reductions in flow, coming to dry out, mainly in places where deforestation was very intense, harming agricultural activities. Moreover, due to fragile soil quality, there has been a gradual change in the areas used for planting and animal raising, which is expanding strongly in the region.

Predatory fishing has threatened the subsistence of the riverine residents (fishermen) and driven them to organize associations that strengthen the fight against predatory fishing and promote the integration between residents of the riverine communities. It was also noted that deforestation to make space for agricultural activities, leads to a gradual reduction in the local biodiversity, especially of the flora and fauna typical to dry land.

The tools applied in this study and their results, including those from the field trips, indicate that the climate change impacts that most need attention, considering the special needs of the Amazon biome are biodiversity, water and agriculture. Based on the results obtained, the research team suggested the following elements for a future plan of action:

- expand the cooperation and exchange of experiences between different areas in the Amazon;

- minimize environmental degradation and guarantee the maintenance of protected areas;

- foster changes in perception, and the involvement of people interested in a shared vision of the what kind life conditions should be achieved in the future, including an awareness of sustainability;

- promote agro-forestry systems as a sustainable alternative for Rondônia;

- broaden lines of credit available to sustainable entrepreneurs, particularly from official banks;

- foster the industrialization of primary resources in activities that according to Bartholo Jr. \& Bursztyn (1999) have social and environmental repercussions, enhancing the value of agro-industrial enterprises with a biotechnological focus, as well as agro-forestry systems that link extractivism and agriculture.

These suggestions invite the understanding that while in some aspects there are similar or related processes in different parts of the Amazon, it is difficult to develop homogeneous criteria for fostering the integration of the Amazon in the context of national economic development. The formulation of a scientifically adequate and specific policy, which respects and enhances traditional populations, while integrating other sectors of the community to promote the sustainable use of the Amazon biome, must be given priority.

According to the social actors and other participants in the study, the main adaptations needed for the region related to adverse climate change are related to the fluctuation and uneven distribution of rainfall, as well as temperature extremes. These factors affect the most vulnerable and needy communities as was clear in the responses given to the question "Adapt to what?". In relation to the issue "What will be affected" those interviewed affirmed that decreased water availability, harming agricultural production and increasing the incidence of various diseases, will be the most prominent items. Educational campaigns (15\%) and rational use of natural resources (19\%) were mentioned as actions for adaptation, although $32 \%$ of respondents did not know how to react to the consequences of future climate events. Even though the community did not have a specific adaptation plan spontaneous adaptation was observed to the degree that, to reduce the adverse effects, farmers for example sought hardier animal and crop species. The suitable local action agenda that was suggested by the researchers who conducted this study should be enacted through a participatory planning workshop with the 
identification of needs and emergencies aimed at the realization of effective actions in the communities of the Gleba Aliança.

From the case study at Tapera it can be inferred, broadly speaking, that its residents make little association between global climate dynamics and daily phenomena. The answers provided by the focal group with the social actors seemed to suggest some degree of knowledge about climate change and possible global implications. Nevertheless, they did not differentiate global climate change from more mundane meteorological variations. The answers invariably focused on issues (Note 10) related to the current precarious living conditions, or to the government's persistant lack of acknowledgement of the community, rather than to possible climate dynamics.

In the issues of "Adapt to what?" or "What will be affected?", the answers pointed to aspects such as: lack of infra-structure (basic sanitation, paved streets, leisure areas, access to education, transportation, and healthcare); occupation of the mangrove by residents; large numbers of abandoned animals; and a high rate of marginal social behavior, particularly related to drug trafficking. With regards to the issue "What would be an adequate local action plan?", the most commented were the following: tree planting; waste recycling; distribution of sunscreen lotion; monitoring of spaces by the public sector; and adoption of maritime transportation to connect the communities and the city.

When addressing the consequences of environmental transformation, but not necessarily connected to climate change, the perception of the decreasing quantity of the mollusk (Anomalocardia brasiliana) or cockles, known locally as berbigão, was a common remark. This reduction in the mollusk population is normally attributed to the effects of real estate development in the mangrove area, and to disrespect, even by the mollusk gatherers themselves, of the periods when capturing this species is prohibited.

With regards to the issues most related to climate dynamics, the social actors most commonly commented that the risk of floods $(81 \%)$ is the most present impact in the community. In fact, floods affect a large portion of the residents, and are especially related to a higher incidence of diseases and health complications - such as flu, asthma, allergies, migraines, skin infections, worms, diarrhea, or other ailments resulting from lack of treated water.

When addressing the capacity of the community to deal with possible risks from extreme climate events, $69 \%$ of interviewees admit not being able to prepare or react to the consequences of climate change, while $19 \%$ did not answer this question. Considering this response and the precarious infrastructure in the community, the researchers evaluated the community's capacity for reaction as fragile. In Table 3 is showed what events most affect their community, interviewees responded intense rain $(88 \%)$, floods $(81 \%)$ and extreme temperatures $(44 \%)$.

When asked to address adaptation to climate change, the social actors consulted point to factors such as education, sanitation, and social services as the most promising strategies, even if they do not specify which actions. In other words, they point to basic sectors that serve the primary needs of any population.

When attempting to identify initiatives for an action plan, the social actors pointed to the need to undertake activities with people involved with recycling, as well as the realization of infrastructure projects to provide the community with appropriate places for garbage disposal. Another aspect given similar emphasis is the evident need to treat waste

As mitigating measures for dealing with risk, the interviewees pointed to the evident need for improvements in infrastructure, including the elements that affect hydrological dynamics, the implications of which include recurring floods, and a permanent condition of poor health among the population. Nevertheless, the social actors in Tapera da Base do not associate a possible increase in their vulnerability to climate dynamics. 
Table 3. Comparison different studies case about events that occur in the region where the families interviewed live, percent by state and total

\begin{tabular}{|c|c|c|c|}
\hline Climate Events * & Rio de Janeiro & Rondonia & Santa Catarina \\
\hline More intense rains & $75 \%$ & $34 \%$ & $88 \%$ \\
\hline High tides, inundations or floods & $58 \%$ & $21 \%$ & $81 \%$ \\
\hline Drought & $14 \%$ & $68 \%$ & $0 \%$ \\
\hline More frequent lack of rain & $22 \%$ & $38 \%$ & $0 \%$ \\
\hline Changes in seasonal flooding of forest & $0 \%$ & $11 \%$ & $0 \%$ \\
\hline More intense heat & $72 \%$ & $83 \%$ & $44 \%$ \\
\hline More intense cold & $53 \%$ & $9 \%$ & $44 \%$ \\
\hline Deforestation & $17 \%$ & $38 \%$ & $31 \%$ \\
\hline $\begin{array}{l}\text { Fire or burnings (accidental or } \\
\text { purposeful) }\end{array}$ & $69 \%$ & $30 \%$ & $19 \%$ \\
\hline Pests & $53 \%$ & $26 \%$ & $38 \%$ \\
\hline Loss of planting area & $6 \%$ & $17 \%$ & $0 \%$ \\
\hline
\end{tabular}

\section{Conclusion}

Based on a theoretical discussion of socio-environmental vulnerability, development and extreme climate phenomena, this paper presents the outcomes of three case studies undertaken in specific regions of Brazil to evaluate the perception of populations deemed already vulnerable, in terms of their knowledge and recognition of climate phenomenon and variations that have affected them. Distinct methodological procedures were used to gather data from the different local actors and populations.

The research was based on the understanding that the climate issue provides an opportunity to reconsider the bases of economic development, characterized as employing specific models for the use of natural resources that can place different populations in situations of risk. These situations become more evident according to the different levels of vulnerability of these populations, in particular those already exposed to social and economic exclusion in countries of late development such as Brazil. Thus, this work began with the premise that a population's vulnerabilities are historically constructed and result from a development model that creates socioeconomic inequalities. When a population is excluded from the development process, it is placed in a situation of risk and often comes to occupy areas designated by law as sites for permanent environmental preservation, as illustrated in the cases of this study, which encompasses populations who occupy mangroves, hillsides and coastal areas.

The threat posed by climate change to the natural bases that sustain life for these communities, and for the planet as a whole, highlights the need to place the ethical and social aspects of this phenomenon on the political agenda. A human rights perspective is thus encompassed, since it is based on the principle that future generations also have a right to the environment.

Properly addressing these conditions of vulnerability, and the impacts of climate events that expose these conditions, involves constructing capacities for resilience that question the understanding of development from a purely economic dimension. In other words, this process must contribute towards the empowerment of communities to facilitate their resilience. Furthermore, the framing of this research tried to contribute to the development of action plans aimed at mitigating vulnerabilities and risks according to the peculiarities of the territories.

The case study of the Fiocruz Campus community observed that all the communities have long suffered from precarious access a route, which has the residents transportation and movements, and have also lacked access to basic public services and infrastructure such as sanitation and health care. These are problems that can be aggravated by extreme climate events, with subsequent implications for living conditions and health. Meanwhile, it is important to help residents in this community become pro-active, because only this way can they push for the changes needed to decrease the vulnerabilities of families facing climate change, and diseases resulting from these events. 
The case study of the Gleba Aliança community clearly demonstrates the great variation of the traditional communities (riverine fishermen) and those with which they co-exist in the surrounding area. Those other communities are constituted mostly of migrants from different regions of Brazil who conduct other types of economic activities (planting and/or cattle rearing), and who have distinct ways of feeling and understanding the interaction with the environment and the effects of climate variations on their lives and means of production. It is necessary to consider these peculiarities to avoid failure when proposing public policies and mitigating actions for the Amazon biome.

The case study of the Tapera da Base community found that the vulnerability of the community is not merely evidence of probable climate threats. The climate transformations understood to be threatening reveal the community's vulnerability to the potential risk of flooding, and other risks such as disease. Therefore, the need for investment in basic actions, constitutionally the responsibility of the state (education, healthcare and infrastructure), is of utmost importance for reducing the community's vulnerability.

For this community, the growing risks associated with threats posed by difficulties common to daily life are still greater than the growing risks related to climate threats, about which residents have little, if any, information. It is worth recalling that more than $80 \%$ of the group interviewed has no knowledge that significant climate changes are taking place. Even when they are made aware of these risks, the residents in the community of Tapera da Base do not reflect upon the need to adapt to possible severe implications of global climate change.

The main priority for the residents of Tapera, and sometimes the only one, is to adapt to the world they live in, given its precarious current state. This manner of channeling attention to socio-economic difficulties to overcome immediate difficulties in the urban environment is both a source of strength for the community, considering that it develops its capacity to prioritize essential aspects, and of growing vulnerability, since it hinders the reflection on the residents' future needs.

Another issue to be highlighted is that the vulnerability of the inhabitants of the communities studied is part of a historic context that naturalizes the risks faced by the economically disadvantaged communities and isolates local social subjects from decision-making processes. This situation is sustained by historic social exclusion, especially in terms of a lack of access to resources, education and basic healthcare. Moreover, the historically structured living conditions of these subjects are subject to different threats, creating a situation in which survival requires adaptation. That is, climate change is only one of the existing threats to which they are historically exposed (others include disease, lack of basic sanitation, various forms of pollution and deforestation).

It is in this sense that a parallel naturalization occurs of the problematic contexts by the part of responsible public and private institutions. The phenomenon of "organized irresponsibility" (Beck, 2006), takes place in this situation, in which to "disguise" the inabilities of the political, scientific and legal spheres to address current risks, institutions act symbolically, creating the sense of a normality and control that are not effective for reducing problems.

Thus, it is important to develop action plans that involve civil society, NGOs and municipal, state and federal agencies to confront environmental disasters and prevent fatalities when they occur.

Considering the three cases, we were able to observe that to foster adaptation of community to climate change, it is necessary to solicit actions that are in tune with the way the system operates at the local level, establishing partnerships with civil defense agencies and municipal governments. It is important to promote changes in the way that a community operates, which can only be accomplished trough dialog among its components that addresses and disseminates information about the main emergency actions in this context of climate change. The goal is to support conditions that can allow community residents to become active social actors in their life trajectory. It is therefore necessary to provide them conditions to interpret the phenomena and its possible implications, and that these and other individuals can have some control of their realities, under the threat of disasters caused or intensified by climate changes.

Future studies should focus on accompanying the establishment of local action plans to confront risks such as flooding and landslides that are intensified by climate change and to verify the participation of the local community, who are the principal interested parties. The local population must be involved in the construction of these plans because they are the ones who know the territory and can contribute to the efficiency of these actions. These studies should be frequently re-evaluated to analyze the effectiveness of the agenda, seeking to mitigate the damage to the vulnerable populations, by increasing their capacity for reaction and readiness. In conjunction, public policies must be planned to build housing to relocate the affected population to safer places less subject to impacts from extreme weather events, yet close to their current homes. This is called for in the guidelines and objectives of the National Protection Policy PNPDC (Law 12.608, of 10/04/2012) and in the strategies for 
reducing risks and disasters proposed by Hyogo in the Disaster Reduction Plan 2005-2015 (UN, 2005). In other words, the actions must be adopted by the various government sectors and should be integrated into various public policies as a transversal theme, to reduce the risks and disasters involving the vulnerable populations.

\section{Acknowledgements}

Our acknowledgments to the respondents who agreed to cooperate with these studies, the Brazilian National Council for Scientific and Technological Development (CNPq), a Fundacao de Amparo a Pesquisa do Espírito Santo/[Research Support Foundation of Espirito Santo] (FAPES) and to the National Foundation for the Development of Private Higher Education/ FUNADESP for their research grants.

\section{References}

Acselrad, H. (2009). O que é justiça ambiental. Rio de Janeiro: Garamond.

Alves, H., Mello, A., D’Antona, A., \& Carmo, R. (2010). Vulnerabilidade socioambiental nos municípios do litoral paulista no contexto das mudanças climáticas. Retrieved from http://www.abep.nepo.unicamp.br/encontro2010/docs_pdf/tema_3/abep2010_2503.pdf

Alves, H. P. F. (2006). Vulnerabilidade socioambiental na metrópole paulistana: uma análise sociodemográfica das situações de sobreposição espacial de problemas e riscos sociais e ambientais. Rev. bras. estud. popul. v.23 n.1 São Paulo jan./jun. http://dx.doi.org/10.1590/S0102-30982006000100004

Bartholo Jr., R. S., \& Bursztyn, M. (1999). Amazônia sustentável: uma estratégia de desenvolvimento para Rondônia 2020. Brasília: IBAMA.

Beck, U. (2006). Living in the World Risk Society. British Journal of Sociology Centennial Professor. London School of Economics and Political Science. February 2006.

Braga, T., Oliveira, E., \& Givisiz, G. (2006). Avaliação de metodologias de mensuração de risco e vulnerabilidade social a desastres naturais associados a mudanças climáticas. Trabalho apresentado no XV encontro nacional de estudos populacionais. São Paulo em Perspectiva, 20(1), 81-95..

BRASIL. Plano Nacional e Mudanças Climáticas. (2008). Decreto no 6.263 (21 / 11 / 2007), Brasília.

Cardona, O. (2003). La necessidad de repensar de manera holística los conceptos de vulnerabilidad y riesgo: una critica y una revisión necesaria para la gestión. Retrieved from http://www.desenredando.org/public/articulos/2003/rmhevr/rmhcvr_may-08-2003.pdf

Da-Silva-Rosa, T., \& Maluf, R. (2010). Populações vulnerabilizadas e o enfrentamento de eventos climáticas extremos: estratégias de adaptação e mitigação. Boletim da Sociedade Brasileira de Economia Ecológica, $23 / 24,40-48$.

Da-Silva-Rosa, T., \& Mattos, R. (2012). Exclusion, Vulnerabilities and Climate Change. In LASA - Latin American Studies Association, 2012, San Francisco. XXX International Congress of the Latin American Studies Association, v. 1.

Füssel, H.-M. (2008). Adaptation to climate change: a new paradigm for action or Just old wine in new skins? International workshop: Prospects of safety and sustainability Science for our globe, Dec 4, Tokyo (Japan).

Füssel, H.-M., \& Klein, R. J. T. (2004). Conceptual frameworks of adaptation to climate change and their applicability to human health, PIK Report No. 91, Potsdam, Germany, August.

Gamba, C. (2010). Avaliação da vulnerabilidade socioambiental dos distritos do município de São Paulo ao processo de escorregamento. Master's Dissertation, Fac. Filosofia, Letras e Ciências Humanas, USP, supervision by Wagner C. Ribeiro.

Giddens, A. (2009). The politics of climate change. Cambridge: Polity Press.

Herrmann, M. L. P. (2001). Levantamento dos desastres naturais ocorridos em Santa Catarina no período de 1980 a 2000. Florianópolis: IOESC, p. 89.

Klein, R. J. T., Schipperc, E. L. F., \& Dessaid, S. (2003). Integrating mitigation and adaptation into climate and development policy: three research questions.

IPCC-Internacional painel for Climate Change. (2007). The Physical Science Basis. Contribution of Working Group I to the Fourth Assessment Report of the Intergovernmental Panel on Climate Change. In S. Solomon, D. Qin, M. Manning, Z. Chen, M. Marquis, K. B. Averyt, M. Tignor, \& H. L. Miller (eds.). Cambridge University Press, Cambridge, United Kingdom and New York, NY, USA. pp. 996. 
Jacobi, P. R. (1995). Moradores e meio ambiente na cidade de São Paulo. Cadernos CEDEC, São Paulo, n. 43.

Magalhães, J. M. (2005). Relatório de Consolidação do PA Aliança. Divisão de Desenvolvimento da Superintendência Regional do INCRA-RO. Porto Velho.

Maluf, R. S., \& Da-Silva-Rosa, T. (2013). Mudanças climáticas, desigualdades sociais e populações vulneráveis no Brasil: construindo capacidades. Rio de Janeiro: CERESAN, 2011. Retrieved from http://www.coepbrasil.org.br/portal/Publico/apresentarArquivo.aspx?TP=1\&ID=8fc52b23-e5bb-4039-96dd -2cacdee9e008\&NOME=Relatorio\%20Final\%20da\%20Pesquisa\%20\%28Volume\%20I\%29.pdf

Marchezini, V. (2009). DOS DESASTRES DA NATUREZA À NATUREZA DOS DESASTRES. In Sociologia dos desastres - construção, interfaces e perspectivas no Brasil/ organizado por Norma Valencio, Mariana Siena, Victor Marchezini e Juliano Costa Gonçalves. São Carlos :RiMa Editora.

Marengo, J. A. (2009). Mudanças climáticas globais e seus efeitos sobre a biodiversidade. Caracterização do clima atual e definições das alterações climáticas para o Território Brasileiro ao longo do século XXI Brasília: MMA.

Mattos, R., \& Da-Silva-Rosa, T. (2011). Reestruturação econômica e segregação sócioespacial: uma análise da Região da Grande Terra Vermelha. In I Seminário Nacional do Programa de Pós-Graduação em Ciências Sociais UFES, 2011, Vitória-ES. Anais do I Seminário Nacional do Programa de Pós-Graduação em Ciências Sociais UFES. Vitória, pp. 1-21.

Mello, A., D’Antona, A., Alves, H., \& e Carmo, R. (2010). Análise da Vulnerabilidade Socioambiental nas Áreas Urbanas do Litoral Norte de São Paulo. V Encontro Nacional da Anppas 4th to 7th October 2010, Florianópolis, SC, Brazil.

Moser, C. (1998). The asset vulnerability framework: reassessing urban poverty reduction strategies. World Development, New York, 26(1).

Sachs, W. (2003). Environment and human rights.Wuppertal Paper 137, September.

Sachs, W. (2008). Climate change and human rights. Development, 51, 332-337. Doi 101057/dev.2008.35.

Valencio, N., Siena, Mariana; Marchezini, Victor e Costa, Juliano. Gonçalves (org.) (2009). Sociologia dos desastres - construção, interfaces e perspectivas no Brasil. São Carlos : RiMa Editora.

Valencio, N. (2011). A sociologia dos desastres: perspectivas para uma sociedade de direitos. Seminário estadual de emergências e desastres: estratégias latino-americanas de enfrentamento à questão. Vitoria, ES.

Zuffo, C. E. (2010). Relatório de estudo de caso: Rondônia. In Projeto de pesquisa "Mudanças climáticas desigualdades sociais e populações vulneráveis no Brasil: construindo capacidades", Porto Velho: COEP.

\section{Notes}

Note 1. COEP has engaged more than 1,100 organizations, thus giving rise to the COEP Network with approximately 20,000 people (the Mobilization Network) from more than 120 communities (the Communities Network).

Note 2. On this subject, COEP was involved with the Database on Climate Practices, Vulnerability and Adaptation (www.coepbrasil.org.br/projetosdeadaptacao) and with the presentation to the government of elements to support the elaboration of the National Plan for Adaptation of Human Impacts by Climate Change, based on discussions held in the working group with the participation of a wide number of social actors.

Note 3. The universities included: the Federal University at Santa Catarina (UFSC), led by Professor Luis D'Agostini and associate researcher Michelle Bonatti; the Federal University at Rondônia UNIR), led by Professors Cátia Zuffo and Joel Magalhães (INCRA).

Note 4. FIOCRUZ - the Oswaldo Cruz Foundation -Mata Atlântica Campus, led by Dr. Andrea Vanini.

Note 5. The study cases originally also included two other biomes that are not discussed in this paper: the Cerrado (tropical savannah biome), which involved a rural quilombola community in Mato Grosso do Sul state, led by Professors Dario Lima Filho and José Jesus Lopes of the Federal University at Mato Grosso do Sul (UFMS); and the Caatinga (xeric shrubland) which is home to family farmers in Pernambuco State, led by Professor Guilherme Soares (Federal Rural University at Pernambuco (UFRPE). 
Note 6. The other two foci are: a survey of national and international reference documents, and national policies related to the theme and a synthesis of their implications for the case studies; and mapping and systematization of knowledge production in Brazil on the theme of climate change and social inequality.

Note 7. We are referring to the disaster occurred in the municipalities of Petropolis, Nova Friburgo and Teresópolis among others hit by intense rains. Generally classified as Brazil's major climatic tragedy, the event caused hundreds of deaths and left hundreds missing as well as infra structure losses. The National Policy on Protection and Civil Defense (Política Nacional de Proteção e Defesa Civil - PNPDEC, L. 12608, April 2012) is considered a direct consequence of this social disaster and mobilization.

Note 8. UNDP/GEF Technical Paper 7. Assessing and Enhancing adaptative capacity, in http://undp.prg/climatechange/adapt/apf.html

Note 9. PAC refers to the federal Growth Acceleration Program, which seeks to improve the living conditions of the local population.

Note 10. "Adapt to what?" Who will be affected? What Will be affected?, How to adapt oneself?" and What would be an adequate local action plan?

\section{Copyrights}

Copyright for this article is retained by the author(s), with first publication rights granted to the journal.

This is an open-access article distributed under the terms and conditions of the Creative Commons Attribution license (http://creativecommons.org/licenses/by/3.0/). 